\title{
A Morphology Index for Characterization of Cell Shape in Candida albicans
}

\author{
By L. A. MERSON-DAVIES* AND F. C. ODDS \\ Department of Microbiology, University of Leicester, PO Box 138, University Road, \\ Leicester LE1 9HN, UK
}

(Received 10 May 1989; revised 17 July 1989; accepted 1 August 1989)

\begin{abstract}
The morphology of Candida albicans cells was determined from their maximum length, maximum diameter and septal diameter in a mathematical ratio, the morphology index (Mi), which usually ranged from approximately 1 for spherical yeast cells to approximately 4 for true hyphae, with elongated yeast cells and pseudohyphae giving intermediate values. Mi could be determined with high reproducibility for $C$. albicans grown in a variety of environments. The highest mean Mi was seen with cells grown in serum and Eagle's medium at $37^{\circ} \mathrm{C}$, the lowest with cells grown in Sabouraud glucose broth at $26^{\circ} \mathrm{C}$. Variant strains of C. albicans gave $\mathrm{Mi}$ values that remained constant in a variety of growth environments. The Mi facilitated detection of two variants that grew exclusively in the yeast form, one that grew as elongated yeasts but could be induced to form pseudohyphae in serum, and one consistently pseudohyphal variant. Cells with a mean $\mathrm{Mi}$ up to $2 \cdot 5$ could be easily separated at septal junctions by mild ultrasonication, whereas cells with a mean Mi greater than 3.5 tended not to separate under these conditions. The chitin content of $C$. albicans cells was almost twice as great in cells with a $\mathrm{Mi}$ approaching 4 as in cells with a Mi close to 1 . The wide range of Mi distributions for a single C. albicans isolate in different environments demonstrates that the fungus does not undergo abrupt changes of morphological phase: rather there are continual changes in morphology between spherical yeasts and true hyphae at the extremes. The study shows that Mi can be used reliably in place of subjective descriptions of morphology to indicate the shape of a C. albicans cell. It should facilitate the detection of molecular and cellular markers specific for morphogenesis in the fungus.
\end{abstract}

\section{INTRODUCTION}

Cells of the pathogenic fungus Candida albicans are capable of development in many diverse morphological forms, and cells of several morphologies frequently coexist in any particular environment (Odds, 1988; Shepherd, 1988). Two principal morphologies are well-recognized: the ovoid, budding yeast form and the filamentous hyphal form. However, many cell shapes intermediate between these two forms occur frequently, so that morphological transitions in $C$. albicans amount to gradations of form rather than a discrete phase change. Intermediate morphologies are loosely termed 'pseudohyphae' but in practice the distinction between elongated yeast cells and pseudohyphae and between true hyphae and pseudohyphae can be difficult to make (Odds, 1988).

Microscopically a pseudohypha does resemble a true hypha but its mode of formation is different, arising by a budding process in which each cell remains attached to its parent and tends towards a narrow, elongated shape (Odds, 1988). Fully developed pseudohyphae may be

\footnotetext{
Abbreviations: AAS, amino acids/salts medium; EMEM, Eagle's minimal essential medium; Mi, morphology index; MSAB, modified Sabouraud broth; SGA, Sabouraud glucose agar; SGB, Sabouraud glucose broth; YNBG, yeast nitrogen base plus glucose.
} 
distinguished from true hyphae only by constriction at septal junctions (Scherwitz et al., 1978; Hedden \& Buck, 1980; Shepherd et al., 1985). McGinnis (1980) has tabulated six features that can be used to distinguish true hyphae and pseudohyphae.

Examples of the blurring of morphological descriptions of $C$. albicans are numerous in the literature. Hrmová \& Drobnica (1981) described cell outgrowths with substantial constrictions at their necks as 'fully grown germ tubes'. Soll et al. (1978) called their filamentous cells 'pseudomycelium' yet in later publications from the same laboratory the cells were referred to as 'mycelium' (e.g. Soll \& Herman, 1983), whilst the strain of C. albicans and the growth conditions used were unchanged. Borgers et al. (1979) appear to have used the terms 'hypha' and 'pseudohypha' interchangeably.

Yokoyama \& Takeo (1983) drew attention to the distinction between short pseudohyphae and yeast cells. The obvious point of difference between yeast cells and any type of pseudohyphae is that the former separate spontaneously whereas the latter must remain in a filamentous chain. However, Gow et al. (1980) were able to shear true hyphae at septal junctions by ultrasonication, so it is possible that pseudohyphae have a propensity for breakage at intercellular junctions even though they may not separate spontaneously.

The present study was undertaken to investigate whether morphological forms of C. albicans could be quantified mathematically and rapidly by the use of computerized image analysis. Precise mathematical definition of morphologies should facilitate definition of cellular and molecular markers specific for different aspects of cell development in C. albicans. It would also allow determination of the distribution of defined morphological types that occur in different environmental conditions.

\section{METHODS}

Fungus and preparation of inocula. C. albicans isolates $73 / 055$ and $73 / 079$ were originally obtained from clinical specimens. Strains Sh 8 (attenuated in mouse-virulence; Loose et al., 1983) and H 12 (hypha-deficient) were kindly provided by Dr D. A. Stevens (Santa Clara Valley Medical Center, California, USA) and hOG 301, a 'mycelial mutant' (Hubbard et al., 1986) was kindly provided by Professor M. G. Shepherd (Experimental Oral Biology Unit, University of Otago, New Zealand). Strains CA2 and MM2002 were kindly furnished by Dr J. F. Ryley (ICI Pharmaceuticals, Cheshire, UK). These two strains do not form germ tubes in serum; they both originated from the laboratory of Dr D. Kerridge (Cambridge, UK) and have been characterized in previous publications (Mattia et al., 1982; Cannon, 1986). All isolates were maintained on Sabouraud glucose agar (SGA; Oxoid mycological peptone $10 \mathrm{~g} \mathrm{I}^{-1}$, glucose $40 \mathrm{~g} \mathrm{l}^{-1}$, agar $20 \mathrm{~g} \mathrm{l}^{-1}$ ).

For preparation of inocula, a loopful of yeasts grown overnight on SGA was added to $50 \mathrm{ml}$ Sabouraud glucose broth (SGB; Oxoid mycological peptone $10 \mathrm{~g} \mathrm{l}^{-1}$; glucose, $40 \mathrm{~g} \mathrm{l}^{-1}$ ) and incubated for $24 \mathrm{~h}$ at $26^{\circ} \mathrm{C}$. The yeasts were harvested by centrifugation at $3000 \mathrm{~g}$ for $5 \mathrm{~min}$, washed twice in sterile, deionized water, and resuspended at a concentration of $5 \times 10^{6}$ cells $\mathrm{ml}^{-1}$ in $0.15 \mathrm{M}-\mathrm{NaCl}$ for $24 \mathrm{~h}$ at $26^{\circ} \mathrm{C}$ to starve the cells. (Of several starvation procedures tested, saline starvation gave the most homogeneous suspensions of single yeast cells, in our hands.) The starved cells were washed twice with sterile, deionized water, resuspended in water and added to prewarmed culture media (see below) at an initial concentration of $1-5 \times 10^{6}$ cells $\mathrm{ml}^{-1}$.

Growth media. Several growth media, selected for their previously described effects on morphological form in $C$. albicans, were used in this study in addition to SGB. Modified Sabouraud broth (MSAB; Evans et al., 1975); amino acids/salts medium (AAS; Lee et al., 1975) supplemented with $70 \mu \mathrm{g}$ arginine $\mathrm{ml}^{-1}$ and adjusted to $\mathrm{pH} 4.5 \mathrm{or} 6.5$ (Bedell et al., 1980); Eagle's minimal essential medium (EMEM; prepared according to Odds et al., 1985); yeast nitrogen base (Difco) containing $55 \mathrm{mM}$-glucose (YNBG); and horse serum (Difco). EMEM cultures were incubated statically at $37^{\circ} \mathrm{C}$ under $5 \%$ (v/v) $\mathrm{CO}_{2}$ in air. All other cultures were shaken at 160 r.p.m. at $26^{\circ} \mathrm{C}, 37^{\circ} \mathrm{C}$ or both, in air.

Measurement of cells. Samples were removed from the cultures at various times after inoculation. Each sample was mixed with $0 \cdot 1$ vol. of formaldehyde/sodium dodecyl sulphate preservative solution (Odds et al., 1985) and stored at room temperature for subsequent microscopic examination. Before examination the cells were allowed to settle, the supernatant was removed and the cells were resuspended in $0.4 \%$ Bacto agar (Difco), which helped to immobilize the cells.

Cell dimensions in all samples were measured with the Imagan 2 computerized image analysis system (Kompira, Strathclyde, UK). Microscopic fields were examined with a $\times 100$ phase contrast objective and viewed with a video camera and their image displayed on the connected monitor. The length $(l)$, maximum diameter $(d)$ and the diameter at septal junctions $(s)$ were all determined for 100 randomly chosen cells (excluding parent yeast cells) in each sample. 
(a)

(b)

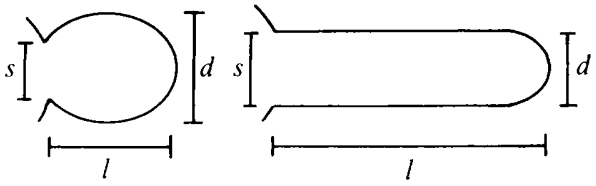

Fig. 1. Principle of calculation of morphology ratio. For each cell, the dimensions $l$ (length), $d$ (maximum diameter) and $s$ (diameter at septal junction) were measured by means of computerized image analysis. The ratio $l / d$ increases with the length of the cell: it approaches unity in a spherical cell (a) but may be very large in a hyphal cell $(b)$. The ratio $d / s$ increases according to the degree of 'ballooning' of the cell : it becomes very large in a cell of spheroidal shape (a) but approaches unity in a parallel-sided hypha $(b)$ where $d=s$. These two ratios were combined in a single expression, $l s / d^{2}:$ the 'morphology ratio'.

For each cell a morphology ratio was calculated from the formula $l s / d^{2}$. The principle of this calculation is shown in Fig. 1. The expression was chosen because it approaches zero for spherical cells with infinitely small septal diameters and increases exponentially, becoming large for elongated cells without septal constrictions. It was considered inconvenient to use a ratio that increased exponentially as morphology changed from spheroidal buds to parallel-sided hyphae. A simple logarithm of the morphology ratio also yielded unwieldy figures which ranged in practice from approximately -3 to 3 . To provide a figure with a more manageable range, a modified expression, $2+1.78 \log _{10}$ 'morphology ratio' was calculated as a 'morphology index' (Mi). The constants were chosen to result in a linearly scaled number, between 0 and 5 and usually between 0.5 and 4.5 , such that an Mi close to 1 indicated spherical yeast cells and an Mi close to 4 indicated long, true hyphal cell units. This range then corresponded broadly with the descriptions of four morphological forms of $C$. albicans given by Yokoyama \& Takeo (1983): an Mi of 2 corresponded with their 'short pseudohyphae' and 3 with their 'long pseudohyphae'.

To determine volumes of $C$. albicans cells and their relation to $\mathrm{Mi}$, ten cells each were measured for $C$. albicans $73 / 055$ grown for $6 \mathrm{~h}$ in AAS (pH 4.5,37 ${ }^{\circ} \mathrm{C}$ ), EMEM $\left(30^{\circ} \mathrm{C}\right.$ and $37^{\circ} \mathrm{C}$ ), SGB at $26^{\circ} \mathrm{C}$, and serum and YNBG both at $37^{\circ} \mathrm{C}$. The volume was measured directly by the image analysis package in terms of volume of the equivalent sphere. Two other formulae for volume determination were also applied to the dimensions of width $(w)$ and length ( $l$ ) obtained for the 60 cells measured, viz. : calculation of the volume of a prolate spheroid, $\left(\pi l w^{2}\right) / 6$ and calculation of the volume of a cylinder with hemispherical end-caps, $\pi w^{3} / 6+\left[\pi w^{2}(l-w)\right] / 4$.

Estimation of cell separation. For estimation of susceptibility of different morphological types to mechanical separation at septal junctions, cell samples with different average Mi were submitted to a brief period of ultrasonication. For each sample, one portion was removed for haemocytometry to estimate the distribution of cell units in aggregates of $1,2,3,4,5$ and 6 or more (for example, two conjoined yeast cells, each with a developing bud were scored as an aggregate of 4 cells; a chain of 3 true hyphal cell units plus a parent yeast cell was similarly scored as an aggregate of 4 cells). From this distribution the number of septal junctions was calculated as one less than the number of cells in each aggregate, and the proportion of septal junctions was calculated as a percentage of the total number of cell units. (A minimum of 100 cell aggregates was counted for each of these determinations.)

The remaining portion of each cell suspension was cooled in ice and ultrasonicated for $10 \mathrm{~s}$ at $40 \mathrm{~W}$ with a $3 \mathrm{~mm}$ diameter probe. The numbers of cell units in each aggregate, the number of septal junctions and percentage of septa were redetermined as before. The extent of cell separation was then estimated as the difference between the percentage septation post-sonication and the percentage septation pre-sonication.

Chitin determination. C. albicans 73/055 was grown in 12 different environments for $6 \mathrm{~h}$, viz.: AAS pH 4.5 and pH 6.5, each at $26^{\circ} \mathrm{C}$ and $37{ }^{\circ} \mathrm{C}$; EMEM at $30^{\circ} \mathrm{C}$ and $37^{\circ} \mathrm{C}$; MSAB at $26^{\circ} \mathrm{C}$ and $40^{\circ} \mathrm{C}$; serum at $37^{\circ} \mathrm{C}$; SGB at $26^{\circ} \mathrm{C}$; andYNBG at $30^{\circ} \mathrm{C}$ and $37^{\circ} \mathrm{C}$. The cells were harvested by centrifugation, washed twice and adjusted to $50 \mathrm{mg}$ wet weight $\mathrm{ml}^{-1}$. Chitin was assayed as glucosamine by the method of Wieckowska (1968). Briefly, a $1 \mathrm{ml}$ portion of each sample was hydrolysed with concentrated $\mathrm{HCl}$ at $100^{\circ} \mathrm{C}$ for $18 \mathrm{~h}$ in a capped tube. The hydrolysate was evaporated to dryness three times over a steam bath and the residue was redissolved in a known volume of water. Alkaline acetyl acetone and Ehrlich's reagent were added and glucosamine concentrations were estimated spectrophotometrically at $526 \mathrm{~nm}$. The remaining portion of each cell sample was used for estimation of dry weight. Chitin content was expressed as $\mu \mathrm{g}$ (mg cell dry weight $)^{-1}$.

\section{RESULTS}

\section{Distribution of morphology indices for $C$. albicans in different growth environments}

C. albicans $73 / 055$ was grown for $6 \mathrm{~h}$ in five different environments. The distributions of morphology indices were different for each environment (Fig. 2). There was a fairly narrow 


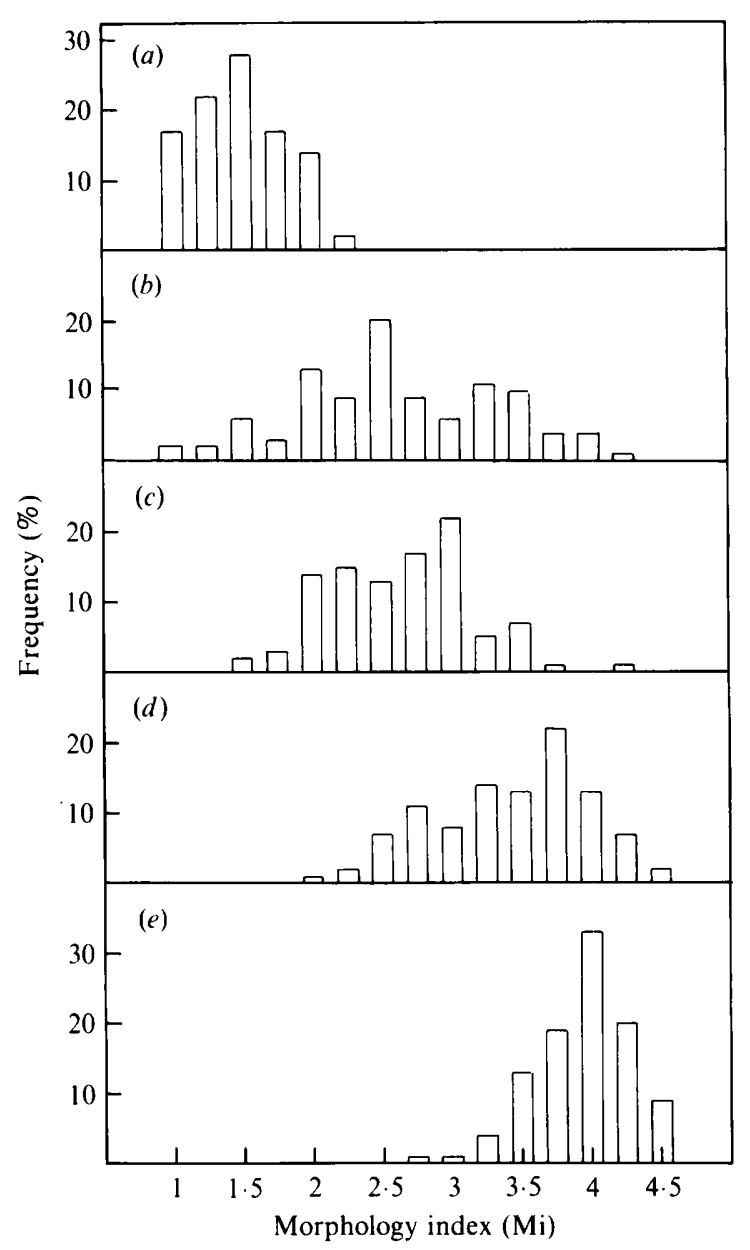

Fig. 2. Frequency distributions of $\mathrm{Mi}$ for $C$. albicans 73/055 grown in five different environments for 6 h. (a) SGB, $26^{\circ} \mathrm{C}$; (b) EMEM, $30^{\circ} \mathrm{C}$; (c) YNBG, $37^{\circ} \mathrm{C}$; (d) MSAB, $40^{\circ} \mathrm{C}$; (e) EMEM, $37^{\circ} \mathrm{C}$.

distribution of $\mathrm{Mi}$ in SGB at $26^{\circ} \mathrm{C}$ and in EMEM at $37^{\circ} \mathrm{C}$. The distribution of Mi was broader in EMEM at $30^{\circ} \mathrm{C}$, YNBG at $37^{\circ} \mathrm{C}$ and MSAB at $40^{\circ} \mathrm{C}$. If C. albicans cells tended to favour particular morphological forms in the manner of an all-or-nothing phase transition, the distributions in Fig. 2 should tend to cluster at particular values of Mi. Since they are spread evenly across a wide range of $\mathrm{Mi}$, this result was interpreted as indicating a continuous distribution of morphological forms in C. albicans, with each environment affecting growth over a range of morphologies. In subsequent experiments, the mean Mi was used as an indicator of the predominant $\mathrm{Mi}$ for each cell population studied.

Table 1 shows the mean Mi for $C$. albicans 73/055 grown for $6 \mathrm{~h}$ in 12 different environments. The data suggest that Mi can be determined with a high degree of reproducibility. In replicate experiments with AAS and YNBG media there was sometimes a wide range of mean $\mathrm{Mi}$ determined, but this probably reflects the broad distribution of Mi found in these media. In EMEM, MSAB, serum and SGB the replicate concordance was extremely good.

The results in Table 1 confirm that Mi adequately reflects the gross morphology of $C$. albicans as a numerical expression. In EMEM at $37^{\circ} \mathrm{C}$ and in serum at $37^{\circ} \mathrm{C}$, the dominant morphological form expected was true hyphae. The mean Mi for these media, 3.7 and 3.5 respectively, can therefore be interpreted as indicating hyphal growth. In AAS (pH 4.5) at $30^{\circ} \mathrm{C}$ and in SGB at $26^{\circ} \mathrm{C}$, the dominant morphological form expected was yeast blastospores, and the 

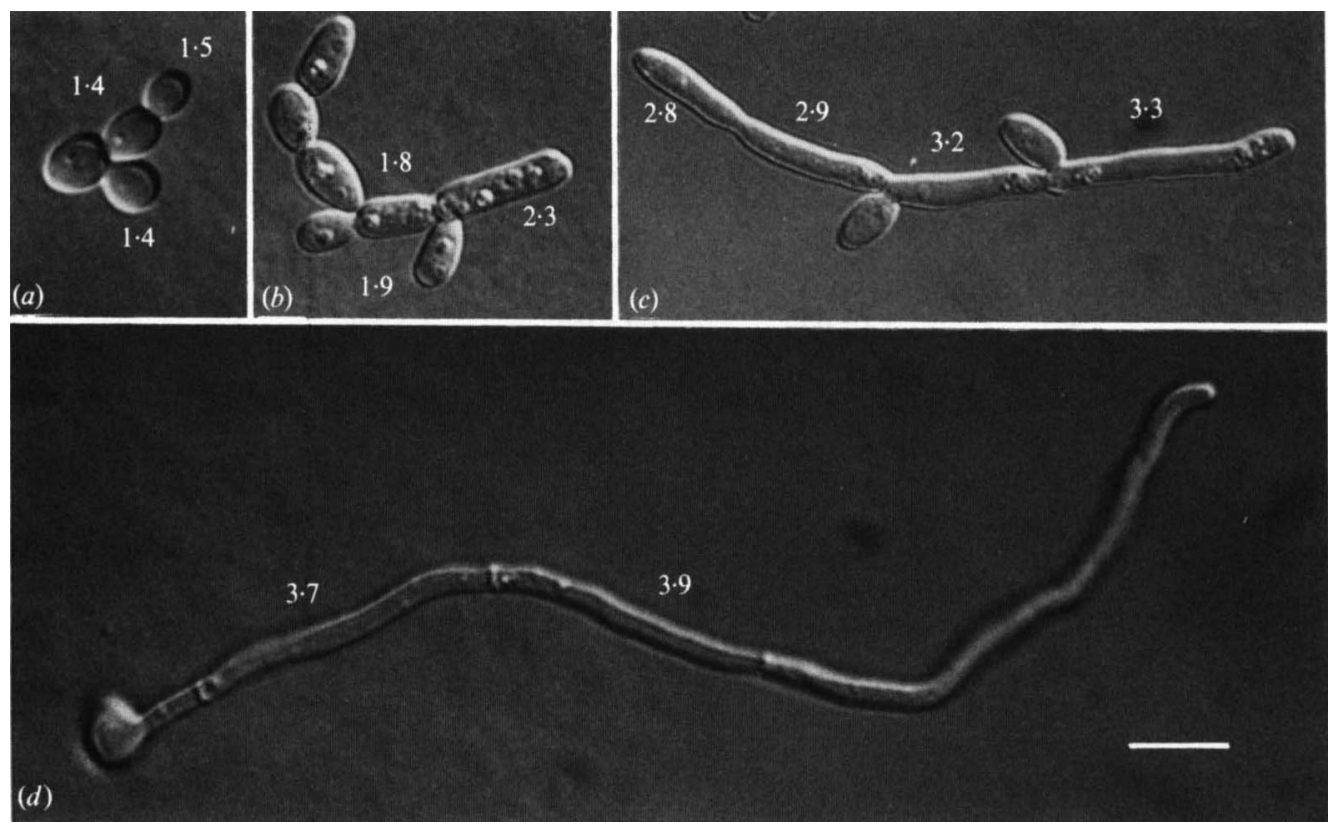

Fig. 3. Micrographs showing different morphologies of $C$. albicans $73 / 055$ grown for $6 \mathrm{~h}$ in four media. The Mi for individual cells is indicated directly on the micrograph. (a) Cells grown in SGB at $26^{\circ} \mathrm{C}$; (b) cells grown in YNBG at $37^{\circ} \mathrm{C}$; (c) cells grown in AAS, pH 6.5, at $37^{\circ} \mathrm{C} ;(d)$ cells grown in serum at $37^{\circ} \mathrm{C}$. Bar, $10 \mu \mathrm{m}$.

Table 1. Mi values for C. albicans 73/055 grown for $6 \mathrm{~h}$ in 12 growth environments

\begin{tabular}{|c|c|c|c|c|}
\hline \multirow[b]{2}{*}{ Growth conditions } & \multicolumn{3}{|c|}{ Mean Mi } & \multirow{2}{*}{$\begin{array}{l}\text { No. of } \\
\text { replicates }\end{array}$} \\
\hline & Range & Average & SD & \\
\hline $\mathrm{AAS} / \mathrm{pH} 4.5 / 30^{\circ} \mathrm{C}$ & $1 \cdot 3$ & $1 \cdot 3$ & 0.0 & 3 \\
\hline $\mathrm{AAS} / \mathrm{pH} 4.5 / 37^{\circ} \mathrm{C}$ & $1 \cdot 3-2 \cdot 5$ & $1 \cdot 7$ & 0.7 & 3 \\
\hline $\mathrm{AAS} / \mathrm{pH} 6.5 / 30^{\circ} \mathrm{C}$ & $1 \cdot 2-1 \cdot 5$ & $1 \cdot 3$ & $0 \cdot 2$ & 3 \\
\hline $\mathrm{AAS} / \mathrm{pH} 6.5 / 37^{\circ} \mathrm{C}$ & $2 \cdot 8-3 \cdot 8$ & $3 \cdot 1$ & 0.6 & 3 \\
\hline $\mathrm{EMEM} / 30^{\circ} \mathrm{C}$ & $2 \cdot 3-3 \cdot 3$ & $2 \cdot 8$ & 0.4 & 7 \\
\hline EMEM $/ 37^{\circ} \mathrm{C}$ & $3 \cdot 5-3 \cdot 8$ & $3 \cdot 7$ & $0 \cdot 1$ & 8 \\
\hline $\mathrm{MSAB} / 30^{\circ} \mathrm{C}$ & $1 \cdot 3-1 \cdot 4$ & $1 \cdot 4$ & 0.0 & 5 \\
\hline $\mathrm{MSAB} / 40^{\circ} \mathrm{C}$ & $2 \cdot 9-3 \cdot 3$ & $3 \cdot 2$ & $0 \cdot 2$ & 5 \\
\hline Serum $/ 37^{\circ} \mathrm{C}$ & $3 \cdot 1-3 \cdot 7$ & $3 \cdot 5$ & $0 \cdot 2$ & 5 \\
\hline $\mathrm{SGB} / 26^{\circ} \mathrm{C}$ & $1 \cdot 2-1 \cdot 3$ & $1 \cdot 3$ & $0 \cdot 1$ & 4 \\
\hline YNBG $/ 30^{\circ} \mathrm{C}$ & $1 \cdot 3-1 \cdot 4$ & 1.4 & $0 \cdot 1$ & 6 \\
\hline YNBG $/ 37^{\circ} \mathrm{C}$ & $1 \cdot 6-3 \cdot 5$ & $2 \cdot 3$ & 0.7 & 7 \\
\hline
\end{tabular}

mean $\mathrm{Mi}(1.3$ in each case) can be interpreted as indicating yeast growth. Thus, intermediate values of $\mathrm{Mi}$ indicate intermediate, usually pseudohyphal, growth forms. On this basis, AAS at $37^{\circ} \mathrm{C}$, EMEM at $30^{\circ} \mathrm{C}$, MSAB at $40^{\circ} \mathrm{C}$ and YNBG at $37^{\circ} \mathrm{C}$ gave mainly intermediate morphologies with $C$. albicans $73 / 055$, rather than spheroidal yeasts or true hyphae.

The association between $\mathrm{Mi}$ and morphology is further exemplified in Fig. 3, where micrographs of different $C$. albicans morphologies are shown in relation to Mi. Yeast cells that are nearly spherical give an Mi between 1 and 1.5 (Fig. $3 a$ ), whereas the Mi for elongated yeast cells is approximately 2 (Fig. $3 b$ ), the Mi for long, pseudohyphal cells is in the range 2.5 to 3.4 (Fig. $3 c$ ) and that for true hyphae is usually greater than 3.4 (Fig. $3 d$ ). 
Table 2. Mi values for $C$. albicans 73/055 sampled at intervals up to $24 \mathrm{~h}$ in three growth environments

The results shown are the means and standard deviations of $\mathrm{Mi}$ for three replicates.

\begin{tabular}{|c|c|c|c|}
\hline \multirow{2}{*}{$\begin{array}{l}\text { Sample time } \\
\text { (h) }\end{array}$} & \multicolumn{3}{|c|}{ Mean $\mathrm{Mi}$ in: } \\
\hline & Serum $/ 37^{\circ} \mathrm{C}$ & $\mathrm{YNBG} / 37^{\circ} \mathrm{C}$ & $\mathrm{SGB} / 26^{\circ} \mathrm{C}$ \\
\hline $\begin{array}{r}2 \\
4 \\
6 \\
8 \\
10 \\
24\end{array}$ & $\begin{array}{l}3.1 \pm 0.1 \\
3.5 \pm 0.1 \\
3 \cdot 6 \pm 0.1 \\
3.3 \pm 0.1 \\
3 \cdot 2 \pm 0.1 \\
3.3 \pm 0.1\end{array}$ & $\begin{array}{l}2 \cdot 1 \pm 0.1 \\
2 \cdot 0 \pm 0.1 \\
2 \cdot 1 \pm 0.2 \\
2 \cdot 0 \pm 0.2 \\
2 \cdot 0 \pm 0.2 \\
1 \cdot 8 \pm 0.3\end{array}$ & $\begin{array}{l}1.3 \pm 0.1 \\
1.3 \pm 0.1 \\
1.3 \pm 0.1 \\
1.2 \pm 0.1 \\
1.3 \pm 0.1 \\
1.3 \pm 0.1\end{array}$ \\
\hline
\end{tabular}

Table 3. Variation in Mi values between seven C. albicans strains grown for $3 h$ in five different environments

The results shown are the means and standard deviations of Mi distributions for each strain in each environment.

\begin{tabular}{|c|c|c|c|c|c|}
\hline \multirow{2}{*}{$\begin{array}{l}\text { C. albicans } \\
\text { strain }\end{array}$} & \multicolumn{5}{|c|}{ Morphology index in: } \\
\hline & EMEM $/ 37^{\circ} \mathrm{C}$ & $\mathrm{SGB} / 37^{\circ} \mathrm{C}$ & Serum $/ 37^{\circ} \mathrm{C}$ & $\mathrm{YNBG} / 26^{\circ} \mathrm{C}$ & YNBG $/ 37^{\circ} \mathrm{C}$ \\
\hline $73 / 055$ & $3.5 \pm 0.5$ & $1.5 \pm 0.6$ & $4 \cdot 1 \pm 0.3$ & $1.4 \pm 0.3$ & $2.6 \pm 0.7$ \\
\hline $73 / 079$ & $3.4 \pm 0.6$ & $1.4 \pm 0.2$ & $4 \cdot 1 \pm 0 \cdot 2$ & $1.5 \pm 0.4$ & $2.8 \pm 0.8$ \\
\hline Sh 8 & $2.9 \pm 0.5$ & $1.7 \pm 0.3$ & $3.9 \pm 0.3$ & $1.8 \pm 0.4$ & $2.4 \pm 0.5$ \\
\hline CA2 & $1 \cdot 4 \pm 0.3$ & $1.4 \pm 0.3$ & $1 \cdot 6 \pm 0.3$ & $1.6 \pm 0.3$ & $1.4 \pm 0.3$ \\
\hline MM2002 & $1.5 \pm 0.3$ & $1 \cdot 3 \pm 0.3$ & $1 \cdot 4 \pm 0.3$ & $1 \cdot 3 \pm 0 \cdot 3$ & $1 \cdot 3 \pm 0.3$ \\
\hline H 12 & $2.0 \pm 0.4$ & $1.5 \pm 0.3$ & $3.0 \pm 0.5$ & $1.6 \pm 0.4$ & $1.6 \pm 0.3$ \\
\hline hOG 301 & $2.9 \pm 0.5$ & $2 \cdot 6 \pm 0.5$ & $2.8 \pm 0.4$ & $2.6 \pm 0.5$ & $2.9 \pm 0.4$ \\
\hline
\end{tabular}

\section{Temporal variations in $\mathrm{Mi}$}

Table 2 shows the mean Mi for C. albicans 73/055 grown in three culture media and sampled at intervals over a period of $24 \mathrm{~h}$. There was little variation in Mi with time of growth in these media : in serum, true hyphae were formed with little reversion to budding by $24 \mathrm{~h}$, in YNBG the dominant form was elongated yeast cells/short pseudohyphae and in SGB only spheroidal yeast cells were evident at all sample times.

\section{Strain variations in $\mathrm{Mi}$}

Table 3 shows the mean Mi for seven strains of $C$. albicans grown in five environments. Strains $73 / 055$ and $73 / 079$, both of which are used routinely in our laboratory as 'typical' $C$. albicans isolates, gave essentially the same $\mathrm{Mi}$ in each medium. Strain $\mathrm{Sh} 8$, although attenuated for virulence in mice, also showed variation in Mi between growth environments; the data indicated morphological responses to environment that were the same as those of $73 / 055$ and 73/079. By contrast, CA2 and MM2002, both well-characterized variants that do not form hyphae, gave mean $\mathrm{Mi}$ in all test media within the range, 1.3 to 1.6 , confirming their purely yeast-forming nature. $\mathrm{H} \mathrm{12}$, a mouse-virulent strain that was included because of our unpublished observation that it is a poor producer of hyphae, gave mean Mi that ranged from only 1.5 to 2.0 in all of the media except serum, where the mean Mi of 3.0 indicated some filamentous cell production. This variant was therefore considered to be a less pure yeast variant than CA2 and MM2002, but it was still not capable of forming true hyphae. Strain hOG 301, described as a 'mycelial mutant' by Hubbard et al. (1986) gave a mean Mi in all five media in the range 2.6 to $2 \cdot 9$. This result confirms that this strain is blocked in the formation of yeast cells; however, the Mi values suggest it is a pseudohyphal, rather than a true hyphal variant.

Separation of $C$. albicans cells at septal junctions

For investigation of the susceptibility of different $C$. albicans morphological forms to mechanical separation at septal junctions, cells of strain $73 / 055$ were grown in four 


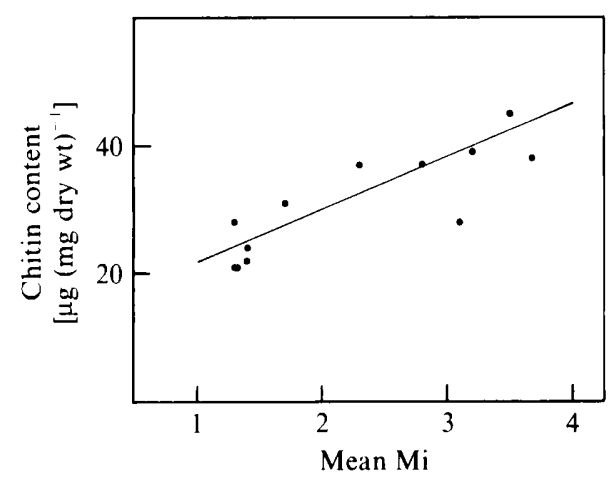

Fig. 4. Chitin content of C. albicans $73 / 055$ grown for $6 \mathrm{~h}$ in 12 different environments (see Methods) to give a range of mean $\mathrm{Mi}$. The least-squares regression line is shown. Correlation coefficient, $r$, is 0.84 .

Table 4. Separation of C. albicans cells of different Mi at septal junctions

C. albicans 73/055 was grown for $5 \mathrm{~h}$ under the conditions shown, then subjected to mild ultrasonication. The figure for percentage separation is the difference between the percentage of septal junctions before and after sonication. Each experiment was repeated seven times.

$\begin{array}{lcc}\quad \begin{array}{c}\text { Growth } \\ \text { conditions }\end{array} & \text { Mean Mi } & \begin{array}{c}\text { Mean percentage } \\ \text { separation }\end{array} \\ \text { SGB } / 26^{\circ} \mathrm{C} & 1 \cdot 2 \pm 0 \cdot 1 & 33 \cdot 1 \pm 10 \cdot 6 \\ \text { AAS } / \mathrm{pH} 6.5 / 26^{\circ} \mathrm{C} & 1 \cdot 8 \pm 0 \cdot 3 & 34.3 \pm 4.4 \\ \text { YNBG } / 37^{\circ} \mathrm{C} & 2 \cdot 5 \pm 0 \cdot 3 & 35.9 \pm 6.3 \\ \text { Serum } / 37^{\circ} \mathrm{C} & 3.9 \pm 0 \cdot 1 & -1 \cdot 2 \pm 9.0\end{array}$

environments to provide a range of $\mathrm{Mi}$ in the cell population. The average separation achieved after a $10 \mathrm{~s}$ period of ultrasonication was of the order of $33 \%$ for cell populations with mean Mi up to 2.5 , but there was little or no separation at septa for cells with a mean Mi of 3.9 (Table 4). These data suggest that septal junctions are susceptible to mechanical separation even in quite elongated pseudohyphae, but that the septal junctions in true hyphae are relatively resistant to separation by mild ultrasonication.

\section{Chitin content of $C$. albicans cells}

Fig. 4 shows the chitin content of $C$. albicans $73 / 055$ whole cells as a function of $\mathrm{Mi}$. The chitin content increased with $\mathrm{Mi}$, from $20-30 \mu \mathrm{g}(\mathrm{mg} \text { cell dry weight })^{-1}$ at $\mathrm{Mi}=1.5$ to more than $40 \mu \mathrm{g}$ $\mathrm{mg}^{-1}$ at $\mathrm{Mi}>3 \cdot 5$.

\section{Volumes of cells with different $\mathrm{Mi}$}

No correlations were found between Mi and cell volume (data not shown), regardless of the basis of volume determination (volume of equivalent sphere, formula based on prolate spheroid, or formula based on cylinder with hemispherical end-caps). The variation in calculated volume between the three methods was enormous. Equivalent sphere volume determinations suggested a range of $20-180 \mu \mathrm{m}^{3}$; for volumes calculated on the prolate spheroid basis the range was 6$40 \mu \mathrm{m}^{3}$ and for volumes calculated on the assumption of cylindrical cells the range was 9$60 \mu \mathrm{m}^{3}$.

\section{DISCUSSION}

Investigation of morphogenesis in $C$. albicans has always been hampered by imprecise definitions of the cellular events involved in the process. In fungi where changes of morphology are clear-cut changes of phase, for example Histoplasma capsulatum and Mucor racemosus, it is a simpler matter to make comparative ultrastructural or molecular analyses of different phases 
than with $C$. albicans, where forms intermediate between the extremes of spheroidal cells and cylindrical cells occur ubiquitously. The present study has shown that an objectively derived expression, $\mathrm{Mi}$, can be used reliably in place of subjective descriptions of morphology to indicate the nature of the shape of a $C$. albicans cell. Mi has the value of being a dimensionless ratio, so that it should give reproducible results with cells of the same morphology regardless of possible differences in precision of measurement that have been noted in the literature on C. albicans cell dimensions (Odds, 1988).

Analysis of C. albicans cell populations in terms of Mi should eliminate much of the confusion that surrounds the literature on Candida morphogenesis. It is possible to determine Mi from published micrographs of $C$. albicans: such an exercise suggests a great disparity between cells described as similar by different authors. To pick on some arbitrarily selected examples: 'germ tubes' according to Evans et al. (1975, Fig. 5B), Lee et al. (1975, Fig. 3) and Shepherd (1988, Fig. 8-1B) show an $\mathrm{Mi}$ in the range 3.6-4.3, confirming that they are true hyphal outgrowths. However, the 'germ tubes' of Hrmová \& Drobnica (1981, Fig. 2E) and of Szaniszlo et al. (1983, Fig. $3 \mathrm{C}$ ) show $\mathrm{Mi}$ in the range 2.4-3.2, which suggests that they are pseudohyphal outgrowths. Since the molecular factors that determine a pseudohyphal outgrowth must differ in some way from those that determine a hyphal outgrowth, it is important that a uniform assessment of morphological form be used if such molecular factors are to be determined reliably.

In this study we have shown that different growth environments generate $C$. albicans cell populations with different distributions of $\mathrm{Mi}$, except where morphologically variant strains are concerned. Demonstration that a $C$. albicans strain gives a consistent mean Mi regardless of growth environment serves both to provide evidence that the strain is a morphologically blocked variant and to indicate the nature of the morphological mutation. It was notable that strain $\mathrm{H} 12$ grew in a form with a higher Mi in serum than in other test media (Table 2): others have previously reported non-filamentous morphological variants of $C$. albicans that nevertheless grow in a pseudohyphal or hyphal form in serum (Corner et al., 1986; Mattia et al., 1982). By contrast, variants such as CA2 and MM2002 were not induced for hypha formation even in serum; their consistently low Mi accords with the previous observations of non-inducibility of these strains (Mattia et al., 1982; Cannon, 1986).

In terms of Mi, EMEM (at $37^{\circ} \mathrm{C}$ ) and serum are the best inducers of true hyphal forms in $C$. albicans, while the AAS medium of Lee et al. (1975) and MSAB (Evans et al., 1975) produce filamentous cells with a lower Mi (Table 1). EMEM at $30^{\circ} \mathrm{C}$ and YNBG at $37^{\circ} \mathrm{C}$ were the two environments in this study that stimulated a substantial cell population with Mi between 2 and 3. For three media, little variation in $\mathrm{Mi}$ was seen in the course of $24 \mathrm{~h}$ of growth, indicating a very stable morphological development in these environments. It is possible that mean $\mathrm{Mi}$ would be less stable throughout the course of prolonged incubation in media such as MSAB and AAS, where reversion of hyphal cells to secondary budding has been described (Evans et al., 1975; Gow \& Gooday, 1984). The data in Table 1 provide a basis for the controlled generation of cell populations with different morphologies to allow for identification of molecules that play a role in morphogenetic processes. Our experiments with chitin content are an example of application of $\mathrm{Mi}$ in this way.

We studied the chitin content of $C$. albicans in relation to Mi since a difference in cell wall chitin level between hyphal and yeast forms is the best known and most consistently confirmed molecular feature that relates to morphology in this fungus. Our finding that whole-cell chitin levels differed by a factor of almost two at the extremes of the Mi range accords with the results of Schwartz \& Larsh (1980), who also analysed the content of intact cells. Chattaway et al. (1968) and Hrmová \& Drobnica (1981) analysed isolated cell walls from different forms of C.albicans. Chattaway et al. (1968) determined a three-fold difference between hyphal and yeast forms, whereas Hrmová \& Drobnica (1981) found only a two-fold difference. Since the Mi of the cells studied by the latter authors was below the range expected for true hyphal cells (see above), the difference may indicate the difference in cell wall chitin content between true and pseudohyphae.

The absence of correlation between $\mathrm{Mi}$ and cell volume at septation may reflect the tendency of $C$. albicans hyphae and pseudohyphae to develop vacuoles so that their overall cell volumes do 
not indicate their true cytoplasmic volumes (Gow \& Gooday, 1984; Yokoyama \& Takeo, 1983). It is possible that future studies will reveal a relationship between volumes of unvacuolated cytoplasm and $\mathrm{Mi}$.

Criticisms of morphogenetic studies of $C$. albicans have previously drawn attention to the need to grow different forms under environmental conditions as closely similar as possible to facilitate distinction between morphology-specific processes and growth medium-specific processes (Odds, 1985; Soll, 1985). Application of Mi does not remove the need for stringency of definition of growth environment for morphogenetic work. Our unsuccessful attempts to relate cell volumes to Mi emphasize this point. In previous studies where cell volumes were found to correlate with morphogenetic and cell developmental markers in $C$. albicans, the different growth forms were obtained in media with only minor differences in their $\mathrm{pH}$ and temperature (Soll et al., 1981).

We examined separation of $C$. albicans cells at septal junctions to discover whether there was a decrease in vulnerability to mechanical separation with increasing Mi. In preliminary experiments (not shown) we gained the impression that some pseudohyphal cell elements were occasionally separated merely by the mild mechanical forces involved in mounting specimens for microscopic examination. We were therefore interested to determine whether vulnerability to separation might be determined reproducibly as a component in mathematical assessment of morphological form. The finding that the extent of mechanically-forced septal separation was essentially the same for all Mi below approximately 3.5 was unexpected. It suggests that a major difference in trans-septal wall structure may be found between true $C$. albicans hyphae and even very long pseudohyphae.

By combining our findings on $\mathrm{Mi}$ and mechanical cell separation with traditional definitions of $C$. albicans morphology and the separation of different pseudohyphal forms by Yokoyama \& Takeo (1983) we believe it is reasonable to define four major morphological types of the fungus as follows. Morphology type 1 : spheroidal yeast elements $\mathrm{Mi}<1.5$; spherical to ovoid cells, of ten seen singly or in groups of up to four budding units with conspicuous constrictions at the sites of septum formation; the longitudinal axes of pairs of these cell elements are rarely co-linear and the elements appear to separate spontaneously. Morphology type 2: elongated ovoid cells, $\mathrm{Mi}=1.5-2.5$; elements similar to spheroidal yeasts but having a more elongated appearance; they are sometimes arranged linearly end-to-end but more often show yeast-like non-colinearity of their longitudinal axes; cell separation is sometimes spontaneous and may be achieved with mild mechanical force. Morphology type 3: pseudohyphal elements, $\mathrm{Mi}=2 \cdot 5-3 \cdot 4$; elongated cells whose sides may be slightly rounded or almost parallel and which are usually arranged in a linear, end-to-end fashion, with obvious constrictions at sites of septum formation; the cells may be separated with mild mechanical force. Morphology type 4: hyphal elements $\mathrm{Mi}>3.4$; parallel-sided, highly elongated cells with minimal constriction at sites of septum formation; these elements are not easily separable by mild mechanical force.

The principal objective of research on morphogenesis in C. albicans is to define and analyse the expression of molecules that determine cell shape. However, overall shape determination is a combination of several cellular processes that must be individually defined if they are to be isolated for experimental study. Use of $\mathrm{Mi}$ is a first step in the precise determination of such cellular processes: once specific shapes can be expressed by an objective mathematical derivation it becomes possible to relate precisely, on a cell-by-cell basis, properties such as reactions with 'hypha-specific' antibodies, locations of actin and microtubules within cells, and so on. Since Mi appears to reveal a continuum of morphologies in C. albicans, the expression may be useful in determining precisely which molecular phenotypes are expressed in relation to changes of shape. Soll et al. (1985) have shown that temporal regulation of apical and general modes of cell wall synthesis is a major determinant of cell shape in C. albicans: it should now be possible to relate timings and quantities of these two modes of synthesis to Mi. Mi also makes possible the analysis of distributions of $C$. albicans growth forms that occur in colonized and infected tissues in vivo. We hope to explore such applications of Mi in future.

Miss Merson-Davies is supported by a studentship from the Science and Engineering Research Council. 


\section{REFERENCES}

Bedell, G. W., Werth, A. \& Soll, D. R. (1980). The regulation of nuclear migration and division during synchronous bud formation in released stationary phase cultures of the yeast Candida albicans. Experimental Cell Research 127, 103-113.

Borgers, M., Vanden Bossche, H., De Brabander, M. \& Van Cutsem, J. (1979). Promotion of pseudomycelium formation of Candida albicans in culture: a morphological study of the effects of miconazole and ketoconazole. Postgraduate Medical Journal 55, 687-691.

CANNON, R. D. (1986). Isolation of a mycelial mutant of Candida albicans. Journal of General Microbiology 132, 2405-2407.

Corner, B. E., Poulter, R. T. M., ShePherd, M. G. \& Sullivan, P. A. (1986). A Candida albicans mutant impaired in the utilisation of $\mathrm{N}$-acetylglucosamine. Journal of General Microbiology 132, 15-19.

Corner, B. E., Poulter, R. T. M., Shepherd, M. G. \& Sullivan, P. A. (1986). A Candida albicans mutant impaired in the utilisation of $N$-acetylglucosamine. Journal of General Microbiology 132, 15-19.

Evans, E. G. V., OdDs, F. C., Richardson, M. D. \& Holland, K. T. (1975). Optimum conditions for initiation of filamentation in Candida albicans. Canadian Journal of Microbiology 21, 338-342.

Gow, N. A. R. \& GoodAy, G. W. (1984). A model for the germ tube formation and mycelial growth of Candida albicans. Sabouraudia 22, 137143.

Gow, N. A. R., Gooday, G. W., Newsam, R. J. \& Gull, K. (1980). Ultrastructure of the septum in Candida albicans. Current Microbiology 4, 357359.

Hedden, G. M. \& BUCK, J. D. (1980). A reemphasis germ tubes diagnostic for Candida albicans have no constrictions. Mycopathologia 70, 95-101.

Hrmoví, M. \& DroBNICA, L. (1981). Induction of mycelial type of development in Candida albicans by low glucose concentration. Mycopathologia 76, 8396.

Hubbard, M. J., Markie, D. \& Poulter, R. T. M. (1986). Isolation and morphological characterization of a mycelial mutant of Candida albicans. Journal of Bacteriology 161, 61-65.

Lee, K. L., BuCKLey, H. R. \& CAMPbell, C. C. (1975). An amino acid liquid synthetic medium for the development of mycelial and yeast forms of Candida albicans. Sabouraudia 13, 148-153.

Loose, D. S., Stevens, D. A., Schurman, D. J. \& FeldMAN, D. (1983). Distribution of a corticosteroid-binding protein in Candida and other fungal genera. Journal of General Microbiology 129, 23792385.

Mattia, E., Carruba, G., Anglolella, L. \& CasSONE, A. (1982). Induction of germ-tube formation by $N$-acetyl-D-glucosamine in Candida albicans: uptake of inducer and germinative response. Journal of Bacteriology 152, 555-562.

MCGINNIS, M. R. (1980). Laboratory Handbook of Medical Mycology, p. 12. New York: Academic Press.
OdDs, F. C. (1985). Morphogenesis in Candida albicans. CRC Critical Reviews in Microbiology 12, 45-93.

OdDs, F. C. (1988). Candida and Candidosis, pp. 42-59. London: Baillière-Tindall.

Ódd, F. C., Cockayne, A., Haywood, J. \& ABbott, A. B. (1985). Effects of imidazole- and triazolederivative antifungal compounds on the growth and morphological development of Candida albicans hyphae. Journal of General Microbiology 131, 25812589.

Scherwitz, C., Martin, R. \& Ueberberg, H. (1978). Ultrastructural investigations of the formation of Candida albicans germ tubes and septa. Sabouraudia 16, 115-124.

SchWartz, D. S. \& LaRSH, H. W. (1980). An effective medium for the selective growth of the yeast or mycelial forms of Candida albicans: biochemical aspects of the two growth forms. Mycopathologia 70, 67-75.

SHEPHERD, M. G. (1988). Morphogenic transformation of fungi. In Current Topics in Medical Mycology, vol. 2, pp. 278-304. Edited by M. R. McGinnis. New York: Springer-Verlag.

Shepherd, M. G., Poulter, R. T. M. \& Sullivan, P. A. (1985). Candida albicans: biology, genetics and pathogenicity. Annual Review of Microbiology 39, 579-614.

Soll, D. R. (1985). Candida albicans. In Fungal Dimorphism: with Emphasis on Fungi Pathogenic to Humans, pp. 167-195. Edited by P. J. Szaniszlo. New York: Plenum.

Soll, D. R. \& Herman, M. A. (1983). Growth and the inducibility of mycelial formation in Candida albicans: single cell analysis using a perfusion chamber. Journal of General Microbiology 129, 2809-2824.

Soll, D. R., Stasi, M. \& Bedell, G. (1978). The regulation of nuclear migration and division during pseudomycelium outgrowth in the dimorphic yeast Candida albicans. Experimental Cell Research 116, 207-215.

Soll, D. R., Bedell, G., Thiel, J. \& Brummell, M. (1981). The dependency of nuclear division on volume in the dimorphic yeast Candida albicans. Experimental Cell Research 133, 55-62.

Soll, D. R., Herman, M. A. \& Staebell, M. A. (1985). The involvement of cell wall expansion in the two modes of mycelium formation of Candida albicans. Journal of General Microbiology 131, 23672375.

Szaniszlo, P. J. JaCobs, C. W. \& Geis, P. A. (1983). Dimorphism: morphological and biochemical aspects. In Fungi Pathogenic for Humans and Animals, part A, pp. 323-436. Edited by D. H. Howard. New York: Marcel Dekker.

WIECKOWSKA, E. (1968). Determination of chitin on the basis of glucosamine content. Chemia analityczna 13, 1311-1317.

Yokoyama, K. \& TAKeo, K. (1983). Differences of asymmetrical division between the pseudohyphal and yeast forms of Candida albicans and their effect on multiplication. Archives of Microbiology 134, 251253. 